\title{
10. \\ MEĐUNARODNI SVEUČILIŠNI \\ CENTAR U ISLAMU GRČKOM I \\ MEDITERANSKA AKADEMSKA \\ ZAJEDNICA: RAZVOJ I PERSPEKTIVE
}

\section{Drago Roksandić}

UDK: 728.81(497.5 Islam Grčki)(083.9)

Sažetak: U radu je predstavljen projekt Medunarodni sveučilišni centar u Islamu Grčkom i mediteranska akademska zajednica: razvoj i perspektive (dalje: Projekt MSC) nastao suradnjom stručnjaka s Agronomskog, Arhitektonskog, Filozofskog i Geodetskog fakulteta Sveučilišta u Zagrebu te iz udruge Društvo za obnovu i revitalizaciju Kule Stojana Jankovića - Mostovi. Predstavljene su okolnosti u okviru kojih je Projekt zamišljen i razvijen, okviri njegova financiranja, aktivnosti i projektni zadatci koji su realizirani, kao i Projektna dokumentacija. Završno izvješće voditelja Projekta MSC-a, autora ovog rada, kritički sažima postignute rezultate slijedeći preuzete obveze i (auto)kritički vrednuje radno funkcioniranje projektnog tima na razini voditelja dionica.

Ključne riječi: Međunarodni sveučilišni centar, Islam Grčki, Kula Stojana Jankovića, obnova, revitalizacija, Ravni kotari

\section{Uvod}

Drojekt Međunarodni sveučilišni centar u Islamu Grčkom i mediteranska akademska zajednica: razvoj i perspektive (dalje: Projekt MSC) nastao je suradnjom stručnjaka s Agronomskog, Arhitektonskog, Filozofskog i Geodetskog fakulteta Sveučilišta u Zagrebu te udruge Društvo za obnovu i revitalizaciju Kule Stojana Jankovića - Mostovi kao ključnoga vanjskog partnera. Proistekao je iz prijave na natječaj Fonda za razvoj Sveučilišta u Zagrebu, na temelju programskih razvojnih odrednica "Zajedno", "Svijet" i "Prostor". Projektna aplikacija od 29., odnosno, 30. listopada 2010. godine bila je prihvaćena na sjednici Senata Sveučilišta u Zagrebu održanoj 8. studenog 2011. godine. Za realizaciju samog Projekta MSC-a, međutim, umjesto zatraženih 409.396,00 kuna odobreno je 300.000,00 kn. Redefinirana projektna dokumentacija od 7. veljače 2012. godine, usklađena s odobrenim 
ukupnim iznosom sredstava, omogućila je potpisivanje Ugovora o dodjeli sredstava Fonda za razvoj Sveučilišta Projektu MSC-a. Ugovor su 30. siječnja 2012. godine potpisali rektor Sveučilišta u Zagrebu prof. dr. sc. Aleksa Bjelišs, dekan Filozofskog fakulteta prof. dr. sc. Damir Boras i voditelj Projekta MSC-a prof. dr. sc. Drago Roksandić. Novčana potpora odnosila se na razdoblje od 1. siječnja do 31. prosinca 2012. godine. (Vidjeti: Ugovor o dodjeli sredstava Fonda za razvoj Sveučilišta /Klasa: 402-08/12-04/3 te Urbroj 380-181/02212-7/). Ugovor je dostavljen voditelju Projekta MSC-a 23. veljače 2012. godine. Ponešto zbog usporenije isplate akontacije od $40 \%$ ugovorenih sredstava (uplata Filozofskom fakultetu izvršena 16. ožujka 2012. godine), a mnogo više zbog rješavanja otvorenih pitanja o načinu financijskog poslovanja Projekta MSC-a između spomenutih sastavnica Sveučilišta u Zagrebu, Ugovor o modalitetima realizacije projekta potpisali su dekani spomenutih sastavnica te voditelj i ovlašteni izvođači Projekta MSC-a tek 30. svibnja 2012. godine. (Vidjeti: Klasa: 740-06/12-01/26 i Urbroj: 3804-850-12-1) Time je na samom početku bio usporen rad na realizaciji ciljeva Projekta MSC-a jer je bujna proljetna vegetacija u kompleksu Kule Stojana Jankovića u Islamu Grčkom (dalje: Kula /u Islamu Grčkom/) otežala i usporila realizaciju prvoga projektnog zadatka, koji je preuzela ekipa prof. dr. sc. Boška Pribičevića s Geodetskog fakulteta, tj. izradbu 3D snimka planiranog prostora MSC-a s 3D laserskim skenerom. Obavljanje tog posla bila je bitna pretpostavka za rad ekipe prof. mr. sc. Alana Brauna s Arhitektonskog fakulteta ("Idejno rješenje rekonstrukcije i prenamjene dijela sklopa Kule Jankovića u Međunarodni sveučilišni centar") i ekipe prof. dr. sc. Branke Aničić s Agronomskog fakulteta ("Studija vanjskog prostora Kule i Međunarodnog sveučilišnog centra sa smjernicama za uređenje”). Neovisno o početnim poteškoćama, svi su partneri u granicama mogućnosti počeli raditi na realizaciji projektnih zadataka te među članovima Projekta MSC-a uopće nije bilo upitno hoće li projekt kao cjelina biti realiziran u jednogodišnjem roku, tj. do svibnja/lipnja 2013. godine, dakle, $s$ neizbježnim polugodišnjim pomicanjem dijela rokova usuglašenih u prihvaćenom "Vremenskom planu aktivnosti s naznakom postaja na kojima se može mjeriti njihovo izvršenje”. Dio aktivnosti, primjerice, realiziranje godišnjih “Desničinih susreta 2012.” od 14. do 16. rujna 2012. godine u Zadru i Islamu Grčkom, morao se održati u izvorno najavljenim terminima. Ključni vanjski suradnik, dr. sc. Uroš Desnica, postojano je bio zaposlen u komunikaciji sa svim drugim članovima Projekta MSC-a. To se na drugačiji način, dakako, odnosi i na projektnog voditelja.

Zaključeni projekt Međunarodni sveučilišni centar u Islamu Grčkom i mediteranska akademska zajednica: razvoj i perspektive čini prije svega projektna dokumentacija:

(A) "3D snimak MSC-a. Geodetske podloge Kule Jankovića i vanjskih prostora";

(B) "Idejno rješenje rekonstrukcije i prenamjene dijela sklopa Kule Jankovića u Međunarodni sveučilišni centar”;

(C) "Studija vanjskog prostora Kule i Međunarodnog sveučilišnog centra sa smjernicama za uređenje";

(D) "Muzeološka studija o mogućnostima prezentacije baštine Kule Stojana Jankovića";

(E) "Desničini susreti. Program društveno-humanističkih i kulturoloških istraživanja Centra za komparativnohistorijske i interkulturne studije Filozofskog fakulteta Sveučilišta u Zagrebu. Izvješće o djelatnostima 2011. - 2013. godine” i

(F) Završno izvješće ključnoga vanjskog suradnika dr. sc. Uroša Desnice. 
Završno izvješće voditelja Projekta MSC-a, prof. dr. sc. Drage Roksandića, kritički sažima postignute rezultate slijedeći preuzete obveze i (auto)kritički vrednuje radno funkcioniranje projektnog tima na razini voditelja dionica.

Svi projektni zadatci realizirani su s punim međusobnim radnim povjerenjem članova projektnog tima, čime su stvorene pretpostavke za nastavak rada na ovome značajnom, a, neupitno, zahtjevnom projektu.

\section{Opis projekta}

U Ministarstvu kulture Republike Hrvatske Kula Stojana Jankovića i crkva sv. Đurđa (k. č. 35 i 39, k.o. Islam Grčki) registrirane su u pravnom statusu "zaštićenoga kulturnog dobra", a po vrsti "nepokretno kulturno dobro - pojedinačno" (Z-2805). Prema Izvodu iz Registra kulturnih dobara Republike Hrvatske Ministarstva kulture (br. 2/2206. od 31. siječnja 2006. godine /NN 124/06/) stoji uistinu opis: "Kula Jankovića je sklop stambenih i gospodarskih zgrada smješten uz povijesnu srednjovjekovnu cestu zvanu "Via magna". Današnji je izgled i raspored sklopa rezultat više građevnih faza od 17. do 20. st. Najstariju jezgru sklopa čini zgrada zvana kula uz koju je sagrađena stambena dvokatnica i više gospodarskih prizemnica. Crkva sv. Đurđa je srednjovjekovna jednobrodna građevina s polukružnom apsidom romaničkih osobina, danas u funkciji mauzoleja obitelji Desnica, vlasnika sklopa."1 O kakvu je kulturnom dobru riječ, u rasponu od prapovijesti do suvremenog doba, iscrpno svjedoči studija Ivana Basića Od domus episcopi do Kule Jankovića. Prostorni razvoj Kule Stojana Jankovića u Islamu Grčkom (2010:88). Kula kao svjedočanstvo epoha od prapovijesti do suvremenog doba nije izuzetak u sjevernoj Dalmaciji, napose u Ravnim kotarima. Samo na benkovačkom području, u zadarskom zaobalju, kojem pripada i Islam Grčki, nalaze se i (pred)rimska Asseria i Nedinum, srednjovjekovni Kaštel Perušić te utvrda Kličevica pa i sam kaštel u Benkovcu itd. Osnivanje Međunarodnoga sveučilišnog centra u Kuli, koja je i sama zaštićeni spomenik kulture, k tome, u kulturnom krajoliku koji je u Hrvatskoj jedan od najraznolikijih, već u samom ishodištu jamči bogat "kulturni kapital”, temelj mnoštva mogućih održivih znanstvenih, obrazovnih i primijenjenih projekata. Pored toga, Kula je idealno stjecište buduće suradnje Sveučilišta u Zagrebu i Sveučilišta u Zadru. Potonje je uostalom cca $15-20 \mathrm{~km}$ udaljeno od Kule i dugoročno je već involvirano u kultiviranju najplodnijih islamskih zemalja ("Baštica"), dakle, u neposrednom je susjedstvu. ${ }^{2}$

Kula je danas vrlo dobro prometno povezana s autocestom A1 (cca $3 \mathrm{~km}$ udaljenosti), Zračnom lukom Zadar (cca $10 \mathrm{~km}$ udaljenosti) te Zadrom, Ninom i Benkovcem (cca 15 $-20 \mathrm{~km}$ udaljenosti). Sve su to vrlo važni preduvjeti za stabilan razvitak MSC-a u Kuli.

1 Izvor: http://www.min-kulture.hr/default.aspx?id=31 (pristup 21. 6. 2013.)

2 2009. i 2010. godine rektor Sveučilišta u Zagrebu prof. dr. sc. Aleksa Bjeliš i rektor Sveučilišta u Zadru prof. dr. sc. Ante Uglešić u nekoliko su navrata raspravljali o mogućnosti da oba sveučilišta zajednički utemelje i razvijaju Međunarodni sveučilišni centar u Kuli. Sveučilište u Zadru je oficijelno podržalo aplikaciju i za ovaj projekt (28. 10. 2010.). S vlasnicima Kule je inače 29. listopada 2009. godine i potpisan načelni Sporazum o utemeljenju Medunarodnoga sveučilišnog centra. Dogovorom rektora prof. dr. sc. Alekse Bjeliša i dekana Filozofskog fakulteta Sveučilišta u Zagrebu prof. dr. sc. Damira Borasa na Filozofskom fakultetu u Zagrebu je formiran Inicijativni odbor za programsku orijentaciju Međunarodnoga sveučilišnog centra u Kuli (predsjednik prof. dr. sc. Drago Roksandić) sa zadatkom da "kapilarno", "odozdo" razvija programske djelatnosti Centra i identificira moguće izvore financiranja. 
Međutim, javni prijevoz je vrlo slab. Jedva da ga ima. Time su nesumnjivo limitirane mogućnosti subregionalnih inicijativa.

Inače, rasprave o mogućim oblicima institucionalizacije kulturnih i znanstveno-istraživačkih djelatnosti u Kuli Stojana Jankovića u Islamu Grčkom započele su već 1988. godine u Jugoslavenskoj akademiji znanosti i umjetnosti (danas: Hrvatska akademija znanosti i umjetnosti). Tada su bile donijete i odluke o utemeljenju i početku rada "Desničnih susreta" (posvećenih vlasniku Kule, piscu Vladanu Desnici /Zadar, 17. rujna 1905. - Zagreb, 4. ožujka 1967./) u Zavodu za hrvatsku povijest. Međutim, pitanje “što s Kulom?” dobilo je svoju punu težinu nakon Domovinskog rata u kojemu je i Kula - po tko zna koji put u svojoj povijesti! - teško stradala. Presudna je bila odluka Ministarstva kulture Republike Hrvatske da njezina povijesna jezgra, kao spomenik kulture, bude obnovljena te da ritam i opseg daljnjih ulaganja bude funkcionalno ovisan o programima sociokulturne revitalizacije nje same, ali i subregionalnog areala gornjih Ravnih kotara u Zadarskoj županiji. Sinergijskim učincima napora koje su u suradnji s odgovornima u Ministarstvu kulture zajednički poduzimali prije svega (a pored ostalih) vlasnici Kule, inače izravni potomci Vladana Desnice i skupina članova Filozofskog fakulteta Sveučilišta u Zagrebu došlo se do projekta kulturnog i znanstveno-istraživačkog centra u Kuli. Od početka je bilo neupitno da projekt bude u funkciji potreba razvoja lokalne zajednice i Zadarske županije kao multietnokonfesionalne zajednice $s$ težištem (a) na kulturnom turizmu i drugim aspektima održivog razvoja te (b) na razvoju hrvatskog i europskog istraživačkog i sveučilišnog nastavnog centra za potrebe preddiplomske, diplomske i poslijediplomske nastave usmjerenom na interkulturne projekte te projekte orijentirane na probleme lokalnog i regionalnog održivog razvoja. Izvorni je radni naziv bio Centar "Vladan Desnica", a trebao je djelovati u sastavu 2001. godine utemeljenog Centra za komparativnohistorijske i interkulturne studije Filozofskog fakulteta Sveučilišta u Zagrebu.

Od 2008./2009. akademske godine sve dotadašnje zajedničke djelatnosti, javno-privatne po svom karakteru, počeli su se usmjeravati spram funkcionalnog i institucionalnog razvoja spomenutog Centra, imajući na umu nužnost da se raspoloživi potencijali što je moguće racionalnije koriste. Budući da se Kula Stojana Jankovića sastoji od fortifikacijskih, rezidencijalnih, gospodarskih, ali i sakralnih i drugih objekata te od kompleksa zemljišta različite namjene (parkovne površine, maslinici, vinogradi, oranice, šume itd.), sve su inicijative bile zamišljene tako da podržavaju cjelovitu zaštitu i revitalizaciju kompleksa. Tada se bila otvorila mogućnost da se korištenjem sredstava Fonda za razvoj Sveučilišta u Zagrebu otvori proces unutarsveučilišnog konstituiranja jezgre stručnjaka različitih profila i specijalnosti koji će napraviti inicijalnu dokumentaciju, "idejna rješenja”, za vrlo složene probleme istovremenog revitaliziranja Kule i osnivanja Međunarodnoga sveučilišnog centra u Kuli. Zahvaljujući brojnim podrškama sa Sveučilišta u Zagrebu i Sveučilišta u Zadru, vlasnika Kule te sa Sveučilišta u Padovi te naporima uključenih nastavnika i suradnika s Agronomskog, Arhitektonskog, Geodetskog i Filozofskog fakulteta te udruge "Društvo prijatelja Kule Stojana Jankovića” aplikacija je napravljena, a nakon što je projekt prihvaćen projektni zadaci su i realizirani.

Od početka, tj. od 2003./2004. godine, bilo je jasno da će trebati tražiti "formule" kojima će se uskladiti dugoročni interesi vlasnika i javnopravnih subjekata. Pitanje je bilo tim složenije što je to usuglašavanje trebalo respektirati i ekskluzivno privatne interese, mnogobrojne privatno-javne te, uvjetno rečeno, ekskluzivno javne interese na temelju dugoročno pravno reguliranih odnosa. Sljedeće konkretno postavljeno pitanje iz javne perspektive bilo je koji će dio Kule, pod kojim uvjetima i na koje vrijeme biti moguće unajmiti za spomenuti Cen- 
tar. Što je vrijeme više protjecalo bilo je jasnije da jedino Sveučilište u Zagrebu u suradnji sa Sveučilištem u Zadru mogu ući u tako zahtjevno zamišljeni projekt. Time se od koncepta interkulturnog centra sve više pomicalo ka konceptu jednoga međusveučilišnog, zagrebačkozadarskog, Međunarodnoga sveučilišnog centra u Kuli Stojana Jankovića. Imajući na umu imperativ da bilo kakve sveučilišne inicijative moraju, u suradnji s vlasnicima, podržavati cjelovitu zaštitu i revitalizaciju kompleksa Kule, otvorilo se pitanje vrednovanja, u dužem povijesnom trajanju, njezina kulturnog krajolika, ali i stvaranja preduvjeta za nalaženje "strateškog partnera" (u jednini ili množini), voljnog podržati obnovu i revitalizaciju kompleksa zemljišta različite namjene (parkovne površine, maslinici, vinogradi, oranice, šume itd.) u posjedu vlasnika. Pritom je posebnu pozornost inicijalno pobuđivao uništeni arboretum, jedan od rijetkih u kontinentalnoj Dalmaciji, kao vrlo zahtjevna parkovna površina. $S$ druge strane, od početka je bilo otvoreno pitanje što bi se sve u Kuli i oko Kule, na "otvorenom", moglo kreativno raditi, a da to bude usklađeno $s$ dominantnim konceptom njezine revitalizacije.

Budući da je Kula tradicijski bila "mjesto sjećanja" s vrlo različitim konotacijama, k tome, mjesto gdje su se u dugom trajanju od ranoga 18. stoljeća nadalje pristizali brojni nepokretni i pokretni kulturni artefakti - ovisno o potrebama i ukusima njezinih imućnih i redovito kulturno radoznalih posjednika - neizbježno se postavilo pitanje "muzealizacije". Brojni su prijedlozi s time u vezi bili predmetom rasprava, a koji su maksimalistički dopirali do projekta muzeja polivalentnih sadržaja, primjerice (a) lokalni ekomuzej Kule Stojana Jankovića kao kompleksnog spomeničkog objekta s ambijentalnim vrijednostima u prijelaznom mediteransko-dinarskom arealu te obiteljskog muzeja s ruralno-urbanim sadržajima glede kulture rada i, općenito, kulture svakidašnjice od 17. do 20. stoljeća i (b) muzej i memorijalna knjižnica obitelji Janković/Desnica te, napose, Vladana Desnice kao jednog od najboljih modernih hrvatskih i srpskih pisaca (eventualno u vezi s projektom artist-inresidence). U svakom slučaju, bilo je nužno suočiti se s potrebom izrade muzeološke studije.

Nužno je isto tako bilo raspraviti kako bi zamišljeni Centar mogao djelovati u skladu s potrebama sveučilišne edukacije i istraživanja. Prevladavalo je mišljenje da bi težište trebalo biti na sadržajima koji mogu involvirati diplomske i poslijediplomske studente, kombinirajući rad u seminarima, vježbama s radioničkim radom i praktičnim sadržajima otvorenima kako lokalno tako i širom Hrvatske i Europe. Pošlo se od toga da bi bilo nužno osposobiti radne sljedeće prostore: (a) jednu polivalentnu dvoranu, koja bi se istovremeno mogla koristiti kao prostor za rad u najmanje tri seminara, (b) radioničke prostore, uređene također za višestruke namjene i (c) rezidencijalni prostor s najmanje 12 dvokrevetnih soba sa studentskim standardom i pet jednokrevetnih soba za nastavne i istraživačke kadrove. U raspravama s vlasnicima uvijek je bila otvorena mogućnost da bi u slučaju potrebe Centar mogao koristiti druge dijelove kompleksa Kule. Međutim i to je trebalo studijski propitati i ponuditi moguća rješenja, dakako, ponovo u dogovoru s vlasnicima. Time je bila zadana projektna agenda i prije nego što je napravljena projektna aplikacija. Politika sveučilišnog Fonda za razvoj dodatno je olakšala odluku da se pritom ide na sveučilišni projekt.

Još nešto, vrlo važno! Projekt Centra u Kuli od početka je zamišljen kao dugoročna inicijativa i, k tome, od početka je bilo neupitno da neće ovisiti o tome kada će biti osiguran za kapitalna investicijska ulaganja u s vlasnicima dogovoreni prostor. Centar je od početka zamišljen kao work-in-progress, odnosno, en construction. Počeo je postojati kada se praktično počelo raditi u obzorju njegovih projiciranih programskih sadržaja. Pritom je obnova djelovanja "Desničinih susreta" 2005. godine, na stotu obljetnicu rođenja Vladana Desnice, imala pouzdano najveći poticajni učinak. 


\section{1. Ostvarene aktivnosti}

\section{1. 1. Geodetski fakultet}

Glavna je zadaća prof. dr. sc. Boška Pribičevića i suradnika s Geodetskog fakulteta bila napraviti 3D snimku MSC-a s 3D skenerom i omogućiti vrhunski kvalitetno obavljanje poslova u drugim dionicama Projekta, napose u dionici prof. mr. sc. Alana Brauna i suradnika s Arhitektonskog fakulteta i prof. dr. sc. Branke Aničić i suradnika s Agronomskog fakulteta. Ovu su ekipu, pored profesora Pribičevića kao voditelja, inicijalno činili doc. dr. sc. Almin Đapo, asistent-znanstveni novak Luka Babić, asistent-znanstveni novak Branko Kordić i asistentica-znanstvena novakinja Vanja Miljković. Završno izvješće iz svibnja 2013. godine potpisali su isti suradnici s izuzetkom kolegice Miljković. Umjesto nje potpisnik je Robert Rodbinić, ing. geod. U 3D snimanju i obradi snimaka prema uvrštenoj dokumentaciji, pored navedenih, sudjelovali su spomenuta Vanja Miljković, Davor Ivančić, geod. i Vjekoslav Krpetić, ing. geod.

Ako se usporedi inicijalne projektne zadatke s realiziranima, vremenski plan aktivnosti je potpuno realiziran pa i premašen. Pored toga što je "kao krajnji rezultat formiran (...) jedinstveni georeferencijalni oblak točaka pogodan za (...) izrad(u) idejnog rješenja budućih sadržaja MSC-a", "izrađeni oblak točaka je uklopljen u ranije izrađeni geodetski snimak (...) iz arhive Zavoda za fotogrametriju Geodetskog fakulteta te su izvršene korekcije na mjestima gdje je [u međuvremenu] došlo do urušavanja...”. Sve podloge koje su dogovarane s profesorom Braunom su mu i predane, a u Završnom izvješću nalaze se skupljene $u$ Prilogu 1 "3D snimak MSC-a. Geodetske podloge Kule Jankovića i vanjskih prostora" s ukupno 17 listova različitih mjerila i veličina.

Drugi dio zadatka bio je "izraditi geodetsku podlogu za potrebe izrade vanjskih prostora kompleksa Kule unutar i izvan zidina”. Zadatak je bio usklađen s projektnim zadatkom profesorice Aničić i suradnika s Agronomskog fakulteta, ali i s dr. sc. Urošem Desnicom, ključnim vanjskim suradnikom i jednim od suvlasnika Kule. Prilog 2 ovoga Završnog izvješća sadržava 3 lista (geodetsku snimku postojećeg stanja i dvije posebne geodetske podloge).

\section{1. 2. Arhitektonski fakultet}

Glavne su zadaće prof. mr. sc. Alana Brauna, dipl. ing. arh. i suradnika s Arhitektonskog fakulteta bile dopuniti postojeću arhitektonsku snimku sjevernog krila Kule te izraditi idejno rješenje MSC-a u tom krilu, inače, izdvojenoj cjelini kompleksa (inicijalno pretpostavljeno cca $650 \mathrm{~m}^{2}$ ). Ovu su ekipu, pored profesora Brauna, kao voditelja, inicijalno činili Mladen Cvitanović, dipl. ing. arh. i Goran Vareško, dipl. ing. arh, stručni suradnici u fakultetskom Zavodu za graditeljsko nasljeđe. Završno izvješće "Idejno rješenje rekonstrukcije i prenamjene dijela sklopa Kule Jankovića u Međunarodni sveučilišni centar" iz svibnja 2013. godine potpisali su profesor Braun kao autor i kolega Cvitanović kao suradnik.

"Idejno rješenje..." čine 18 stranica teksta s dvije slike i jednom tablicom ("Iskaz neto površina”, str. 17) te 18 listova u Grafičkom dijelu studije. List 1 "Zemljopisni položaj. Smještaj naselja u Ravnim kotarima” (mjerilo 1:20000), s naglašenom lokacijom Islama Grčkog i Kule te trasom autoceste A1 i prometnica prema Zadru, izvrsno je svjedočanstvo o prednostima položaja Kule. Postojeće stanje Kule s označenim predloženim dijelovima MSC-a u mjerilu 1:500 (list 2), njihovi detaljniji prikazi u mjerilu 1:200 (list 3), stanje pročelja u spomenutom mjerilu (presjeci 1-1, 2-2) (list 4), fotografije postojećeg stanja s težištem na objektima "sjeverne fronte" (list 5) te varijantom 1 idejnog rješenja (tlocrt prizemlja, tlocrt 
potkrovlja) u istom mjerilu (list 6), tlocrt krovova u varijanti 1 (1:200) (list 6a), pročelja, presjeci 1-1, 2-2 u istoj varijanti (1:200) (list 7), org. jedinice - smještaj (tlocrt prizemlja, tlocrt potkrovlja) u varijanti $1(1: 100)$ (list 8$)$, org. jedinice - nastava i uprava (tlocrt prizemlja) u varijanti 1 (1:100) (list 9), org. jedinice - nastava (tlocrt prizemlja) u varijanti 1 (1:100) (list 10), org. jedinice - ugostiteljstvo (tlocrt prizemlja) u varijanti 1 (1:100) (list 11). Od lista 12 do lista 17 su analogna rješenja u varijanti 2. List 18 predstavlja idejno rješenje $\mathrm{u}$ trodimenzionalnim prikazima. Iskazi površina u jednoj i drugoj varijanti su: dormitorij $115 \mathrm{~m}^{2} / 160 \mathrm{~m}^{2}$; office/tehnika $15 \mathrm{~m}^{2} / 15 \mathrm{~m}^{2}$; stan domara $45 \mathrm{~m}^{2} / 55 \mathrm{~m}^{2}$; dvorana + spremišta $60 \mathrm{~m}^{2} / 60 \mathrm{~m}^{2}$; ulazni prostor + administracija $35 \mathrm{~m}^{2} / 35 \mathrm{~m}^{2}$; sanitarije $25 \mathrm{~m}^{2} / 25 \mathrm{~m}^{2}$; knjižnica + računalna učionica $60 \mathrm{~m}^{2} / 60 \mathrm{~m}^{2}$; radionice $55 \mathrm{~m}^{2} / 60 \mathrm{~m}^{2}$; restoran $100 \mathrm{~m}^{2} /$ cafe-bar $75 \mathrm{~m}^{2}$; sanitarije $25 \mathrm{~m}^{2} / 25 \mathrm{~m}^{2}$ i info $0 \mathrm{~m}^{2} / 15 \mathrm{~m}^{2}$. U oba je slučaj ukupna površina MSC-a $525 \mathrm{~m}^{2}$.

Studija ističe da idejno rješenje obuhvaća "prostor sjeveroistočnog, gospodarskog krila s neposrednim vanjskim prostorima. Gospodarsko krilo sastoji se iz tri prizemnice i jednog, $s$ tri strane ograđenog, vanjskog zida. Današnje stanje (...) nažalost je ruševno. Niti jedna gospodarska zgrada nema sačuvan krov, a dio krila na samom zapadnom uglu potpuno je srušen" (Braun 2013:13). Potom se konstatira da je projektni zadatak bio ponuditi idejno rješenje obnove, rekonstrukcije i prenamjene spomenutog prostora za potrebe MSC-a, predviđajući prostore za boravak, rad i okrjepu cca 30 - 40 studenata i nastavnika, uključujući i nesmetano kretanje osoba s invaliditetom i smanjenom pokretljivošću (ibid.). Imajući na umu da je riječ o izuzetno izduženom volumenu, "ideja novog Međunarodnog sveučilišnog centra upravo je u linearnom nizanju grupa sadržaja duž njegove uzdužne osi” (ibid. 14). Smještajni dio, obrazovni prostori i ugostiteljski sadržaji svaki su u zasebnom dijelu kompleksa i samostalno komuniciraju s vanjskim prostorima. Osigurane su, dakako, i neophodne unutarnje veze i komunikacije. Prvo idejno rješenje iz 2012. godine pokazalo je da u spomenute prostore "sjeverne fronte" Kule nije moguće smjestiti sve sadržaje budućeg MSC-a. Rješenje je traženo, dakako u suradnji s vlasnicima, u proširenju prostornog zahvata "i to u dva smjera: vlasnik sklopa bi budućem Centru na raspolaganje stavio i ruševne prostore uz sam ulaz u Kulu Jankovića, dok bi se nastava na otvorenom mogla održavati na terasi prvog kata zgrade zvane "Kotarina", a problematika smještaja i prehrane studenata rješavala bi (se) u prostorima nekadašnje osnovne škole u Islamu Grčkom ...” (ibid. 15). U tom su smislu napravljene spomenute dvije varijante idejnog rješenja MSC-a, koje imaju niz zajedničkih obilježja, npr.: "Izrazita linearna organizacija Centra zahtijevala je artikulaciju neposrednih vanjskih prostora koji su zamišljeni kao uzdužne šetnice s kojim se "puni" i "prazni” Centar. Svi sadržaji Centra imaju ulaz s unutarnje šetnice koja je projektirana kao izdignuta drvena paluba s trajnim elementima za zaštitu od sunca u vidu guste pergole. (...) Svaka organizaciona jedinica Centra ima ulaz i s vanjske pristupne površine: središnji ulaz, smještajni sklop te prostori radionica unutar obrazovnog dijela Centra." (ibid. 15-16). Varijanta 2 nastala je prije svega na molbu vlasnika da se stan domara smjesti na samom istočnom uglu Centra. Time je povećan smještajni dio, ali su izgubljene radionice MSC-a, a ugostiteljstvo je izmješteno iz Kule, odnosno, reducirano na cafe-bar (ibid. 16). Predviđeno je oblikovanje volumena i detalja upotrebom tradicionalnih materijala (kamen, vapnena žbuka, kupa kanalica). Osvjetljenje je moralo biti pojačano preko krovnih prozora na unutarnjoj plohi krova (ibid.). Studija inače preporuča rješenje problema parkiranja na drugoj strani prometnice.

Voditelj Projekta MSC-a inicirao je raspravu o mogućnostima obnove i prenamjene dijela napuštene osnovne škole u Islamu Grčkom, u walking-distance od Kule. Time bi se 
mogao osigurati smještaj za većinu korisnika usluga Centra (kako studenata tako i nastavnika), primjerenije bi se moglo osigurati prehranu, rekreaciju te, napose, radionički prostor za specifične potrebe (primjerice, za arheološka i etnološka istraživanja) itd. Revitalizacija inače solidno građene osnovne škole - prostora nužno otvorenijeg lokalnom stanovništvu - mogla bi olakšati osiguranje investicijskih sredstava za MSC u Kuli.

\section{1. 3. Agronomski fakultet}

Rad ekipe na Agronomskom fakultetu, s prof. dr. sc. Brankom Aničić na čelu, također je realiziran u cijelosti prema Vremenskom planu aktivnosti s pomakom koji su imale i druge ekipe. U ovoj su ekipi, pored voditeljice, inicijalno bili uvršteni prof. Stanko Stergaršek, d.i.a., asistentica Iva Rechner Dika, mag. ing. prosp. arch. i znanstvena novakinja dr. sc. Petra Pereković, mag. ing. prosp. arch. Završno izvješće "Studija vanjskog prostora Kule i Međunarodnog sveučilišnog centra sa smjernicama za uređenje" od 26. svibnja 2013. godine, potpisali su profesorica Aničić kao autorica, doc. dr. sc. Petra Pereković kao koautorica te dr. sc. Iva Rechner Dika i prof. Stanko Stergaršek kao suradnici. Grafičku obradu idejnog rješenja radile su studentice I. Bunjak-Pajdek i N. Malbaša. Studija je rađena u stalnoj suradnji s dr. sc. Urošem Desnicom, a obilno je korištena i dokumentacija u njegovu posjedu. Institucionalni izrađivač je Zavod za ukrasno bilje, krajobraznu arhitekturu i vrtnu umjetnost Agronomskog fakulteta Sveučilišta u Zagrebu.

Studija, opsega 52 stranice, sadržava i 20 priloga, 10 karata i 55 slika, a u nastavku kartu posebne geodetske podloge, napravljenu u timu profesora Pribičevića te karte "Kula Stojana Jankovića. Idejno rješenje. Idejno rješenje cijelog posjeda", "Kula Stojana Jankovića. Idejno rješenje. Idejno rješenje - uži otvoreni prostor uz kompleks Kule Jankovića i MSC" te "Kula Stojana Jankovića. Idejno rješenje. Idejno rješenje užeg otvorenog prostora uz kompleks Kule Jankovića i MSC-a - shema komunikacija”.

U kumulativnom dijelu Završnog izvješća potrebno je istaknuti, koristeći obavijesti iz ove studije, da se kompleks Kule s imanjem prostire na cca 10 ha, pri čemu je zemljište u blagom padu od istoka prema zapadu (od 164,72 m do $124 \mathrm{~m} \mathrm{NV}$ ). Kula i crkva sv. Đurđa nalaze se na najvišim točkama (Kula od 162 do 157 m NV, a crkva na 165,4 m NV). Mjestimično su nagibi terena jače izraženi (preko 30\%), a većim su dijelom blagi (oko 7\%). Izvjesno je da bi bilo kakva intervencija u prostoru prije svega morala poštivati postojeću konfiguraciju terena (Aničić 2013:32). Nužno je izraziti suglasnost is svije kontrastne evaluacije: Prvo, "(z)elene površine na lokaciji iznimno su značajan element čitavoga kompleksa, koji utječe na visoke estetske i vizualne kvalitete prostora" i, drugo, "(d)anas na cjelokupnoj parceli prevladava razvijena vegetacija uz pojedinačne primjerke visoke vegetacije s obilježjima sukcesije i prelaska travnjačkih ili livadnih ploha u šikaru. (ibid. 36). Kada je o kulturnom krajoliku koji Kulu već metaforički čini prepoznatljivom riječ, u studiji je umjesno naglašeno da se "na cjelokupnoj površini pojavljuju (...) pojedinačna odrasla stabla koja djeluju kao upečatljivi akcenti (najčešće jablani i čempresi visokih uskih krošanja)" (ibid.).

Korisnici ove studije posebno će morati imati na umu da je navedena površina kompleksa Kule složena, što će neizbježno imati višestruke posljedice za daljnju fazu projektiranja i programiranja MSC-a te za krucijalne daljnje sporazume i ugovore s vlasnicima Kule: "Postojeću namjenu površina čini nekoliko glavnih zona; kompleks kule s prednjim i unutrašnjim dvorištem (velika i mala avlija, zona 1 i 2), područje crkve sv. Đurđa (zona 3), perivojni dio u središnjem dijelu imanja (zona $4 \mathrm{a}$ i $4 \mathrm{~b}$ ) te zapadni dio imanja s pretežno poljoprivred nom namjenom (zona 5). Za sve navedene zone zadržala bi se prioritetna 
namjena uz jedinu veću izmjenu u kontaktu vanjskog prostora s dijelom građevine koji će se prenamijeniti u Međunarodni sveučilišni centar (MSC) s pratećim objektima. Ta zona uključit će vanjske namjene i sadržaje koje su neizbježne za funkcioniranje takvog kompleksa (komunikacijski vanjski prostor, boravišni prostor i eventualno vanjska učionica). $S$ obzirom da se MSC otvara i na unutrašnja dvorišta (veliku ali i djelomično na malu avliju) te istočni dio vanjskih površina prema guvnu, tu se očekuju najveće sadržajne promjene vanjskog prostora. Zone 3 i 4 su obije parkovne zone no sa specifičnim smjernicama za oblikovanje posebno prostora oko crkve sv. Đurđa. Također zona $3 \mathrm{i} / \mathrm{ili} 1$ trebale bi i sadržajno uklopiti potrebu za izgradnjom manjeg broja parkirališnih mjesta” (ibid. 39).

Suglašavajući se s ovakvim pristupom, izdvojio bih svoje mišljenje u dva pitanja. Osobno sam krajnje nesklon zagovarati bilo kakve parkirališne površine u arealu Kule. Naročito to ne bih mogao prihvatiti u neposrednoj blizini prostora "Guvna", gdje bi doista bilo potrebno urediti, kao što Studija i predlaže, radni prostor na otvorenom, a koji bi, prema potrebi, mogao biti korišten i kao scena za različite artističke programe u izravnoj funkciji djelovanja MSC-a. K tome, parkiralište bi nužno "pokrilo" i dio površine napuštenog groblja za koje arheolozi s pravom pretpostavljaju da je jedno od potencijalno najizdašnijih arheoloških nalazišta u ovom dijelu Ravnih kotara. Ono bi remetilo i ugođaj oko crkve sv. Đurđa, smještenoj u neposrednoj blizini. Drugo je pitanje bitno jednostavnije, a tiče se razine otvorenosti pogleda od crkve sv. Đurđa prema jugu. Mišljenja sam da bi trebao biti što otvoreniji, tim više što je predviđeno postaviti odmorište s klupom ispred crkve. Budući da je u crkvi, pored ostalih Jankovića i Desnica, sahranjen pisac Vladan Desnica, otvoren pogled s klupe pred crkvom na Ravne kotare i Zadar imao bi i simbolički veliki značaj.

Studija obiluje poticajnim uvidima i prijedlozima rješenja. Njezina je velika prednost u tome što maksimalno vrednuje tradicijske vrijednosti okoliša Kule, koliko god i gdje god je to moguće - imajući na umu kontinuitete i diskontinuitete, ali i razinu dokumentiranosti tradicija, potom, ona istovremeno vrednuje i privatne i (moguće) javne interese i vizure, nastojeći ih međusobno razlučiti, ali i uskladiti kada god je to moguće. Ne ulazeći u detalje, htio bih naglasiti potrebu za daljnjom raspravom o "Velikoj avliji". Budući da je ona u 19. i 20. stoljeću mijenjala svoje statuse i funkcije, izvjesno je da ona i u budućnosti na nov način može imati svoje privatno-javne sadržaje i djelatnosti. Iako se predloženo rješenje odnosi samo na dio njezine kompleksne problematike, mislim da bi trebalo krenuti od njega, tj. "preispitati mogućnost oblikovanja vanjskog prostora za manifestacije različitog oblika (prezentacije, izložbe na otvorenom, kulturne večeri, manji koncerti, vanjske radionice i sl. za potrebe događanja vezanih za muzej/galeriju Kule Jankovića i sveučilišni kampus)" (ibid.:41). Budući da će povijesna jezgra Kule ionako imati naglašeni memorijalno-muzeološki karakter, bit će naglašenija potreba za programskim usuglašavanjem djelatnosti s djelatnošću MSC-a. Koliko je to osjetljivo pitanje najbolje svjedoči vrlo umjesno upozorenje iz Studije da "ulazni prostor u Međunarodni sveučilišni centar - komunikacije i eventualni boravišni dio [treba] oblikovati na način da se ne naruši postojeći karakter velike avlije i na način da se ne naruši reprezentativnost ulaznog dijela osobito u potezu glavni ulaz u dvorište (kapija) - glavnu ulaz u građevinu" (ibid. 45).

Što god se dogovaralo u vezi s MSC-om, nužno je imati na umu da će na lokalnoj, županijskoj i državnoj razini pa i u međunarodnim kontekstima trebati osigurati mnogo povoljniji pravni i razvojni status Kule i njezina okoliša, Islama Grčkog i Latinskog, Kašića, Gregurice itd. Prema Prostornom planu Zadarske županije (dalje: PPZŽ) iz 2006. godine, Islam Grčki nalazi se u ravnokotarskom zaobalnom prostoru. Poljoprivredne aktivnosti 
vrlo visokog i visokog intenziteta prioritetne su u razvojnom planiranju. U njemu je naglašena i važnost zaštite "značajnih i vrijednih poljodjelskih kompleksa". Prostorni plan uređenja Grada Benkovca (2012.) u osnovi na isti način vrednuje Islam Grčki, s time što je "(z)a lokalitete Brložina i Kovačevići propisana ... izrada prostornog plana užeg područja odnosno Urbanističkog plana uređenja ...” (ibid. 19-21). Pogled na kartu zadarskih županijskih prostorno-razvojnih cjelina nameće zaključak da je Islam Grčki s Islamom Latinskim i Kašićem areal u kojemu se dotiču zadarska urbana regija te prostor podvelebitskog kanala (ibid.). Potonje nigdje u dokumentima ne piše, a dovoljno je uspeti se za lijepa vremena na vrh Kule pa vidjeti ono što spomenuta karta sugerira. Ljudski pogled doseže preko Zadra do zadarskih otoka, a, $s$ druge strane, obuhvaća podvelebitske predjele, Novigradsko i Karinsko more te masiv Velebita. Sva prirodna i kulturna raznolikost tog dijela Hrvatske vidi se $s$ vrha islamske Kule kao na dlanu i to usred njegova najplodnijeg predjela.

Iako Zadarska županija ““"obiluje” prostorima koji su zbog svoje geomorfološke, biološke i krajobrazne raznolikosti registrirani pod određenim stupnjem zaštite, u Islamu Grčkom je benkovačkim planom iz 2008. godine registriran park uz Kulu kao vrijedna parkovna površina, koju je potrebno zaštititi i urediti sukladno predloženoj kategoriji zaštite..." (ibid.:23). PPZŽ registrira u Islamu Grčkom kao zaštićene graditeljske spomenike povijesno kulturne baštine crkvu sv. Đurđa i Kulu te arheološki lokalitet Crkvine, a benkovački iz 2012. godine, pored navedenih, uključuje i arheološki lokalitet Vreline-Ciciline Bujaduše i prapovijesni lokalitet Graduša-Lokve (ibid. 25).

Posebna je vrijednost Studije što otvara i dugoročnije projicirana pitanja mjesta Agronomskog fakulteta Sveučilišta u Zagrebu kao i Sveučilišta u Zagrebu i Sveučilišta u Zadru općenito u projektima u Kuli i Ravnim kotarima koji će povezivati izvorne obrazovne i znanstvene funkcije MCS-a s razvojnim politikama u lokalnom i regionalnom obzorju: "Veličina posjeda i nedostatak kontinuirane njege pogoduju sukcesiji, te je zbog održivosti novo uređenog perivoja potrebno osmisliti dodatni oblik suradnje na temelju kojeg bi se kroz edukaciju taj prostor i održavao. Da bi se ovom posjedu vratio stari i prepoznatljivi ladanjski sjaj potreban je duži period intenzivne njege i kontinuiranog održavanja. Za to je potreban stalan nadzor i određeni ljudski resursi koji bi se brinuli o tom prostoru. Iz tog razloga u budućnosti bi se mogla uspostaviti suradnja s poljoprivrednim školama i/ili fakultetima (Sveučilište u Zadru i Sveučilište u Zagrebu) kako bi dio posjeda bio poligon studentske prakse, istraživanja i slično. Na njemu bi se promovirao uzgoj starih autohtonih sorti voćaka i povrća i učilo o izgubljenim i napuštenim kulturama koje su nekad postojale na ovom arealu. U dijelu kompleksa Kule i avlijama moguće je kroz uzgoj raznolikog mediteranskog bilja također učiti i prepoznavati njihova botanička svojstava i karakteristike. Moguće je i putem stručnih radionica raditi na postepenoj izgradnji i obnovi krajobrazno arhitektonskih elemenata (staza, zidova, kamenih struktura i sl.). U sklopu održavanja i vizije održivog gospodarenja potrebno je i moguće kroz dobro osmišljene projekte za to i osiguravati dodatna poticajna financijska sredstva" (ibid. 54).

\section{1. 4. Filozofski fakultet: muzeološka studija}

Glavna je zadaća inicijalnog sastava tima koji su činili prof. dr. sc. Tomislav Šola te znanstveni novaci-asistenti Darko Babić i Željka Miklošević - svi s Katedre za muzeologiju Odsjeka za informacijske i komunikacijske znanosti Filozofskog fakulteta Sveučilišta u Zagrebu - bila izraditi muzeološku studiju o prezentaciji bogate baštine Kule, što je uključivalo njezine raznolike elemente i mjesta sjećanja (napose u vezi s piscem Vladanom Desnicom) 
te mikroregije gornjih Ravnih kotara, s otvorenim obzorjima prema Zadru, otocima i Velebitu. Završno izvješće "Muzeološka studija o mogućnostima prezentacije baštine Kule Stojana Jankovića" iz lipnja 2013. godine potpisuje dr. sc. Darko Babić, operativni voditelj muzeološke dionice Projekta MSC-a, koji je u međuvremenu preuzeo punu odgovornost za ovu studiju, u suradnji s kolegicom Željkom Miklošević.

Muzeološki segment Projekta MSC-a, fokusiran na prezentaciju baštine Kule Stojana Jankovića, zaključen je izradom muzeološke studije koja predstavlja - sukladno zadanim projektnim ciljevima - cjeloviti prijedlog muzeološkog rješenja. Svojom cjelovitošću on postaje, i predstavlja, osnovni dokument za daljnje aktivnosti vezane uz raznovrsne oblike i metode interpretacije i komunikacije kako vrijednosti baštine Kule tako i njezina šireg okoliša. Važno je istaknuti da završna muzeološka studija uvažava i integrira sve dionike Projekta MSC-a - vlasnike Kule i zbirki pokretnih kulturnih dobara kumuliranih u Kuli u dužem razdoblju te jednako tako i svih projektnih partnera. Posebna je pažnja posvećena poželjnim sinergijskim učincima između djelatnosti Međunarodnog sveučilišnog centra Sveučilišta u Zagrebu (u osnivanju) i muzejskim projektima i aktivnostima u Kuli. Na tom tragu dodatno su konzultirani, za određene segmente studije, i određeni renomirani stručnjaci u svijetu u području muzeologije/upravljanja baštinom.

Sukladno predviđenom vremenskom planu provođenja aktivnosti dionice D, Muzeološka studija o prezentaciji baštine Kule bila je podijeljena u dvije osnovne faze. Tijekom prvih šest mjeseci trajanja Projekta MSC-a involvirani naprijed navedeni stručnjaci za ovu dionicu provodili su nužna preliminarna istraživanja vezana uz potencijale i mogućnosti upotrebe kulturne i prirodne baštine. Ona su se odnosila izravno na Kulu, uključujući njezine raznolike elemente, napose one vezane uz Vladana Desnicu. Uključivala su jednako tako i baštinske potencijale kao i mogućnosti baštinske interpretacije šireg areala mikroregije gornjih Ravnih kotara, grada Zadra i Velebita. Pritom je ponajviše bila korištena građa dostupna u zagrebačkim knjižnicama, muzejima i arhivima.

Istovremeno, napravljena su i komparativna muzeološka istraživanja vezana uz primjere dobre prakse interpretacije i prezentacije baštine koji imaju sličnosti s ovim projektnim zadatkom. U tom segmentu vrijedi posebno istaknuti iskustvo "Heathland Centre Lygra" (Vrištinski centar na otoku Lygra) u Norveškoj. ${ }^{3}$ Ovaj, više puta nagrađivani Centar, iako situacijski vrlo različit od ravnokotarskog okoliša, vrlo je poticajan kao primjer sveukupne interpretacije teritorija i svojevrsnog neformalnog ekomuzeja. Poticajan je i zato što je bio pokrenut na inicijativu profesora s norveškog Sveučilišta u Bergenu. Razvio se kao izvrstan primjer kvalitetne suradnje akademskog i muzejskog sektora. Tijekom prvih pola godine pored navedenih istraživanja ostvarene su i dvije značajne razmjene ideja s relevantnim stručnjacima u području muzeologije i upravljanja baštinom. Iako aktivnosti o kojima je riječ nisu bile financirane iz sredstava Fonda za razvoj Sveučilišta u Zagrebu, važne su jer su osigurale značajno kvalitetniju razinu izvedbe projektnih zadataka. Radi se o radnim sastancima s uglednim svjetskim stručnjakom na području muzejskog dizajna, dr. sc. Georgeom Jacobom te $s \mathrm{dr}$. sc. Clintonom Timothyjem Curlom, višim istraživačem kanadskog Muzeja ljudskih prava (u izgradnji). Kolega Babić je sa spomenutim stručnjacima raspravio mogućnosti buduće suradnje. Ovaj oblik dodatnog angažmana na projektnim marginama, ali bez projektne financijske podrške, nastavljen je i u drugoj, završnoj fazi.

3 http://www.coast-alive.eu/content/heathland-centre-lygra i http://www.muho.no/en/the-heathland-centre-at-lygra/ (pristup 22. 6. 2013.). 
Odlaskom profesora Šole s Katedre za muzeologiju, koja je bila nositelj ovog dijela Projekta MSC-a, dr. sc. Darko Babić je kao dotadašnji prvi suradnik preuzeo punu odgovornost za oblikovanje i finalizaciju studije. Izradio je prvu, radnu verziju muzeološke studije uz asistenciju kolegice Željke Miklošević na određenim, manjim, dijelovima studije. Ova je verzija pažljivo analizirana i usklađivana online komunikacijom, ali i na više sastanaka s vlasnicima Kule i zbirki koje čine okosnicu muzeološke studije. Stalna komunikacija održavana je i s voditeljem Projekta MSC-a te s drugim projektnim partnerima.

Istovremeno $s$ ova dva procesa slijedile su i povremene konzultacije oko pojedinih segmenta vezanih uz modele i oblike moguće prezentacije slojevite baštine Kule s nekoliko vodećih muzejskih i baštinskih profesionalaca. Među njima treba izdvojiti profesora Amareswara Galla te Susan Cross iz Europske asocijacije za interpretaciju baštine. Spomenuta i nespomenuta imena svjetskih stručnjaka sada već čine svojevrsni neformalni međunarodni savjetodavni konzorcij muzeoloških rješenja u Kuli i njezinu okolišu, koji neupitno predstavlja dodatnu vrijednost u ovom projektu.

$\mathrm{Na}$ sadržajnoj razini muzeološka studija u svom prvom dijelu detaljno analizira zadane okolnosti lokaliteta (Kule Stojana Jankovića) kao izravnog prostora muzeološke intervencije, zbirki koje su na raspolaganju za upravljanje i moguće izlaganje te zadanosti koje proizlaze iz postojećeg Zakona o muzejima, izdvojenih segmenata iz Pravilnika vezanih uz muzejske institucije i muzeološko djelovanje kao i Registra muzeja u Republici Hrvatskoj (kojeg vodi Muzejski dokumentacijski centar u Zagrebu). U ovom dijelu studije istaknuti su potencijali koje Kula Stojana Jankovića sa svojim zbirkama posjeduje (uz pretpostavku da će iste, s obzirom da su neke još uvijek dislocirane, biti na raspolaganju za realizaciju željene interpretacije i prezentacije baštine) uz poseban osvrt na ograničenja i obveze koje propisuje Zakon o muzejima i relevantni Pravilnici. U tom kontekstu treba istaknuti da ne postoje prepreke da se muzeološko djelovanje u Kuli Stojana Jankovića prepozna kao muzejska ustanova (u osnivanju) uz uvjet da se formalno riješi status zbirki (adekvatnost čuvanja i izlaganja predmeta). Nadalje sugerira se da je potrebno u najskorijem roku riješiti pitanje formalnog osnivača muzeja pri čemu je predloženo nekoliko rješenja, uz sugestiju da isti bude formiran u obliku javno-privatnog partnerstva koji nadilazi forme prisutne u postojećem Zakonu o muzejima. Ova forma najkvalitetnije odgovara zadanoj situaciji premda u Republici Hrvatskoj ista nije dovoljno često prisutna u segmentu kulturnih institucija, to je praksa koja u zapadnoj Europi te Sjedinjenim Američkim Državama i Kanadi nije rijetka i uspješno funkcionira. Alternativna predložena rješenja jesu osnivanje muzeja od strane Sveučilišta u Zagrebu, Hrvatskog povijesnog muzeja ili kao podružnice jednog od lokalnih/ regionalnih muzeja (npr. Zavičajni muzej Benkovac). Nadasve značajna ograničenja koje implicira postojeći Zakon o muzejima i relevantni Pravilnici vezani su uz prostor, oprema i sredstva za rad koje svaki muzej mora posjedovati i njima je posvećena posebna pažnja. U ovom segmentu muzeološka studija ukazuje da, ukoliko se odabere opcija osnivanja samostalnog muzeja, trenutna i realno projicirana buduća opcija podrazumijeva formiranje samostalnog lokalnog, a po muzeološkim karakteristikama općeg muzeja premda ukazuje i ovdje na neke moguće alternative.

U glavom dijelu, razradi muzeološke studije uzeti su u obzir svi prethodno izneseni stavovi te pravne implikacije koje proizlaze iz Zakona o muzejima i povezanim pravilnicima i predložena muzeološka koncepcija razvoja muzejske institucije u kompleksu Kule je s njima u skladu. Osnovna ideja koncepcije je usklađena suvremenim muzeološkim tendencijama i praksi izlaganja u muzejskim ustanovama/institucijama - transformaciji od muzeja pred- 
meta u pravcu muzeja ideje. Napose se slijede načela interpretacije i prezentacije baštine koja su prakticirali ekomuzeji u Francuskoj u drugoj polovini 20. stoljeća. Osnovna ideja ekomuzejskog pokreta očituje se na razini odnosa ustanove spram cjelokupnog teritorija te zbirke spram sveukupne (kulturne i prirodne) baštine, kao i u aktivnoj involviranosti lokalnog stanovništva kao dionika baštine. Ova se načela vrlo kreativno mogu vrlo reprezentativno primijeniti u slučaju bogatog nasljeđa Kule Stojana Jankovića, imajući na umu aktere, događanja i lokalne osobitosti. Idealno bi Kula trebala istovremeno biti ishodišna točka za analogno upoznavanje prostora gornjih Ravnih kotara. Time bi u Kuli još jače mogao doći do izražaja Vladan Desnica, kao čovjek i djelo, kao krucijalna baštinska vrijednost, kao nadasve važna dimenzija - univerzalna ideja interkulturalizma.

Sukladno tome je i pretpostavljeni muzejski obilazak baziran upravo na ova tri segmenta. U nevelikim prostorima "Stare kuće" koji su rezervirani za muzeološku interpretaciju i prezentaciju (cca $410 \mathrm{~m}^{2}$ ), prizemlje je predloženo za interpretaciju bogate povijesti mikroregije s naglaskom na Kuli. Prvi kat je usmjeren na prezentaciju ideje interkulturalizma u rasponu od poimanja interkulturalizma do specifičnog, konkretnog mikroregionalnog konteksta, s težištem na Kuli. Time se stvara idealni uvod u muzeološku prezentaciju koja slijedi na drugom katu, posvećenu piscu Vladanu Desnici (svojevrsna memorijalna kuća/soba-muzej koji, na osnovu bogatog osobnog narativa emitira univerzalne vrijednosti). Dodatni interpretacijski elementi, uključeni u muzeološku koncepciju, podrazumijevaju zadržavanje određenih prostora (soba) u njihovu nekadašnjem izvornom (sada rekonstruiranom) obliku koji kvalitetno pridonose tumačenju svih triju osnovnih vrijednosti koje ovaj muzej ima za cilj. Planirano interpretacijsko upoznavanje $s$ vanjskim prostorima (gumno, crkvica sv. Đurđa, arboretum, poljoprivredne površine, ...) slijedi ekomuzeološku logiku prezentacije baštine i osigurava dodatnu vrijednost muzeološkog upoznavanja s Kulom Stojana Jankovića.

Pored navedene, neupitno izvedive muzeološke koncepcije u trenutno zadatim okolnostima, muzeološka studija iznosi i temeljna stajališta o mogućnostima daljnjeg razvoja muzeološke prezentacije i interpretacije u vezi s razvojnim mogućnostima MSC-a, što, pored ostalog, uključuje mogućnosti arhitektonskih intervencija. Međutim, to su pitanja koja ostaju otvorena za budućnost i ovise o značajnim dodatnim sredstvima.

Zaključena muzeološka studija u tom smislu pretendira postati osnovnim dokument sve daljnje aktivnosti vezane uz raznovrsne oblike i metode interpretacije i komunikacije vrijednosti baštine Kule i šireg okoliša. Ona treba biti i osnovna podloga za eventualnu prijavu za strukturne fondove Europske unije.

\section{1. 5. Filozofski fakultet: "Desničini susreti”}

U jesen 2010. godine, kada je rad na ovoj projektnoj aplikaciji dosegao svoj zenit, Program društveno-humanističkih i kulturoloških istraživanja Desničini susreti bio je već u trećoj godini svoga kritičkog propitivanja moderne intelektualne historije. Od svog osnutka, 1989. godine i napose od obnove svoje djelatnosti, 2005. godine, Desničini susreti - izvorno posvećeni kritičkom propitivanju opusa Vladana Desnice (Zadar, 17. rujna 1905. - Zagreb, 4. ožujka 1967.) - nastojali su podržavati i kulturu kritičkog propitivanja vremena u kojemu je Desnica živio. Ovakvi Desničini susreti, koji se svake godine u rujnu održavaju u Zagrebu ili Zadru te svaki put i u Kuli u Islamu Grčkom, dokaz su da je Međunarodni sveučilišni centar u Desničinoj Kuli doista work-in-progress, da taj Centar u svojoj jezgri već sada postoji. Godine 1990. te od 2005. do 2012., dakle, u svim godinama kada su se 
održavali, u njihovu je radu sudjelovalo 158 sudionika iz Hrvatske, Austrije, Belgije, Bosne i Hercegovine, Češke, Francuske, Italije, Nizozemske, Njemačke, Poljske, Sjedinjenih Američkih Država, Slovenije i Srbije. Dakle, od početka svog djelovanja oni su par excellence međunarodni sveučilišni i kulturni fenomen.

Drugo je njihovo obilježje da su od obnove svoje djelatnosti 2005. godine - na stotu obljetnicu rođenja Vladana Desnice - Desničini susreti interinstitucionalni program. Na Filozofskom fakultetu Sveučilišta u Zagrebu, gdje su 1989. godine bili utemeljeni u sastavu Zavoda za hrvatsku povijest, od svoje obnove 2005. godine ustrojbeno su vezani za Centar za komparativnohistorijske i interkulturne studije. Ovaj je Centar izvorno bio konstituiran u Zavodu za hrvatsku povijest, ali je 2007. godine legaliziran kao ustrojbena jedinica Filozofskog fakulteta, a 2012. godine, nakon što je na Fakultetskom vijeću usvojen njegov Pravilnik, ušao je u novu fazu svog djelovanja. Još je jedna fakultetska ustrojbena jedinica, Odsjek za kroatistiku, u statusu utemeljitelja u Desničinim susretima. Pored toga, utemeljiteljski status imaju i Hrvatsko društvo pisaca iz Zagreba te Srpsko kulturno društvo "Prosvjeta", također iz Zagreba. Njihovi predstavnici, tj. akademik Krešimir Nemec, prof. dr. sc. Drago Roksandić, Velimir Visković i Čedomir Višnjić čine stalni sastav Pripremnog odbora. Ovisno o "velikoj temi" sljedećih Desničinih susreta, Pripremni odbor se dopunjava s jednim ili dva stručnjaka, stručnjaka za izabranu "veliku temu". Tako su članovi bili i prof. dr. sc. Ivo Banac, prof. dr. sc. Zvonko Kovač, akademik Zoran Kravar itd.

Treće je njihovo obilježje - u izravnoj vezi s podnaslovom Desničinih susreta - poticanje inter- i transdisciplinarnog dijaloga i to preko granica "paradigmi". Pristupi imanentni povijesti društva kao i povijesti kulture u Desničinim susretima ne isključuju se. Naprotiv. Time su veliku vrijednost dobili inovativni pristupi intelektualnoj historiji, čime je, dakako, dodatno pojačan interes za opus Vladana Desnice.

Četvrto je njihovo obilježje inter- i transgeneracijski dijalog. Iako ljudi koji su obnovili Desničine susrete potječu, neovisno o osobnim svjetonazorima iz svijeta "šezdeset i osme", u inicijativama Desničinih susreta sudjeluju sve akademski aktivne generacije, od najmlađih do, uvjetno, najstarijih. Njihova su "motorna snaga" dobrim dijelom poslijediplomski doktorski studenti. Tajnici Pripremnog odbora redovito su doktorandi (Magdalena Najbar-Agičić 2009. i 2010.; Branimir Janković 2011. i 2012.; Filip Šimetin Šegvić i Nikolina Šimetin Šegvić, 2013.). Njihova je i kreativna i operativna uloga redovito vrlo velika. Broj doktoranada koji ravnopravno sudjeluju u radu Desničinih susreta u stalnom je porastu posljednjih godina (godina 2013. bila je prva, privremena, iznimka). Tajnici Pripremnog odbora u suradnji s programskim voditeljem, prof. dr. sc. Dragom Roksandićem, iz godine u godinu prije održavanja Desničinih susreta realiziraju "programsku knjižicu”, koja sadržava različite informativne tekstove te, napose, program rada, sažetke priopćenja i biobibliografske obavijesti o sudionicima. "Programske knjižice" rađene su uvijek po najvišim standardima u nas te imaju svoj CIP zapis i ISBN. Redovito ih se distribuira u pdf obliku na vrlo veliki broj adresa. Tako je bilo i 2011., 2012. i 2013., a bit će tako i ubuduće.

Desničini susreti postojano drže do kulture znanstvenog dijaloga. S izuzetkom skupa održanog 2013. - posvećena temi "Intelektualac danas", koji je održan na Sveučilištu u Zadru i u Kuli u Islamu Grčkom od 20. do 22. rujna 2013. i za koji su sudionici dogovoreni odlukama Pripremnog odbora i pozvani osobnim pismima - svi prethodni skupovi obznanjivani su javnim pozivima za prijave. To je uključivalo, kao što je to obično slučaj, obrazloženi prijedlog teme i raspravu na Pripremnom odboru o mogućim problemskim usmjerenjima skupa u okviru unaprijed dogovorene "velike teme". "Velika tema" Desničinih 
susreta 2009. bila je "Intelektualci i vlast, 1945.-1954.", Desničinih susreta 2010. "Ideologija vlasti i ideologičnost teksta", Desničinih susreta 2011. i Desničinih susreta 2012. "Intelektualci i rat, 1939.-1947." "Velika tema" Desničinih susreta 2013. Bila je "Intelektualac danas", čime se prvi put tematski izašlo izvan obzorja kronološkog vremena Vladana Desnice samog, ali se zato dosljednije "zaokružila" problematika epohalnog (samo)razumijevanja intelektualaca od kraja 19. do početka 21. stoljeća. Time se i prije održavanja skupa uspijevalo osigurati fokusiranje na inovativne pristupe na samom skupu. Drugo, potičući prihvaćene sudionike da prije održavanja skupa distribuiraju što je moguće iscrpnije dijelove svojih priopćenja bilo je moguće, $s$ jedne strane, ograničiti dužinu izlaganja priopćenja na 10 do 15 minuta, a, s druge strane, otvoriti što više mogućnosti za kritičku raspravu povodom pojedinih priopćenja, tematski povezanih priopćenja ili same "velike teme" skupa. Time se dodatno poticalo sudionike da nastave raditi na svojim tekstovima poslije završetka rada skupa. Treće, sa zadovoljstvom se može konstatirati da se kvaliteta članaka pripremljenih za objavljivanje povećava u prosjeku iz godine u godinu. Tome (vjerojatno) doprinose i Upute suradnicima za pisanje priloga u Zborniku, koje su u osnovi ustaljene od početka objavljivanja serije Zbornika radova Desničinih susreta, ali je još sigurnije da je uvođenje dvostrukog recenziranja svakoga pojedinog članka (u pravilu, jedan recenzent iz Hrvatske i jedan iz inozemstva) utjecalo da "produženje" dijaloškog ozračja i poslije održavanja samog skupa.

Budući da je Pripremni odbor zaključio da je potrebno uložiti napor da se svaki novi svezak Zbornika prezentira na prvim sljedećim Desničinim susretima, nije potrebno posebno isticati da Desničini susreti funkcioniraju cijele godine, od skupa do skupa. Time dolazimo do Biblioteke Desničini susreti Centra za komparativnohistorijska i interkulturna istraživanja. Zbornike radova Desničini susreti od početka zajednički, kao suurednici, uređuju prof. dr. sc. Drago Roksandić i Ivana Cvijović Javorina, prof. i doktorandica. Do sada je u Biblioteci objavljeno sedam svezaka, a zadnji, osmi svezak Zbornika radova Desničini susreti 2012.: Intelektualci i rat, 1939. - 1947. objavljen je u dva sveska te se može reći da je to bio dosad najveći izdavački poduhvat Desničinih susreta (cca 700 kartica teksta).

Riječ je o nastavku trenda započetog sa Zbornikom radova Desničini susreti 2011., koji je s uvođenjem spomenute dvije recenzije za svaki članak, UDK broja za svaki članak te u svakom slučaju sažetka i ključnih riječi na hrvatskom i engleskom, popisa izvora i literature, a na kraju kazala i popisa recenzenata. Time je zadan znanstveni i nakladnički standard ispod kojeg se ne bi smjelo ići, što, dakako, iziskuje i veće izdatke.

Publikacija Vladan Desnica $i$ Desničini susreti: pogled unatrag, pogled unaprijed (2012.) rezultat je stjecaja okolnosti u kojemu su se podudarile potreba da se na istovremeno dokumentaran i kritički način vrednuje 25-godišnje iskustvo Desničinih susreta te da se povodom izlaska iz tiska "prekretničkog" Zbornika radova Desničini susreti 2011. u Zagrebu, u Multimedijalnoj dvorani Knjižnice Filozofskog fakulteta i u Beogradu, u Amfiteatru Narodne biblioteke Srbije, vrednujući ostvareno otvori raspravu o daljnjim mogućnostima razvitka Desničnih susreta.

Načelno, problema nema jer su Desničini susreti ionako definirani kao program društveno-humanističkih i kulturoloških istraživanja. Nema razloga da pored svoga godišnjeg skupa i svega što ga prati ne počnu razvijati druga područja djelovanja, koja bi mogla isto tako biti integrirana u programske aktivnosti Međunarodnoga sveučilišnog centra u Kuli. Činjenica da je Centar za komparativnohistorijska i interkulturna istraživanja registriran za vrlo široki spektar aktivnosti bitno olakšava daljnje jačanje funkcija i potencijala Desničinih 
susreta u razvitku Međunarodnoga sveučilišnog centra u Kuli te istovremeno na Sveučilištu u Zagrebu i, u skladu sa zajednički dogovorenim interesima, na Sveučilištu u Zadru.

S ulaskom Republike Hrvatske u Europsku uniju postaje važnije nego ikada pitanje prevođenja s hrvatskog na mnoštvo jezika te s mnoštva jezika na hrvatski. (Kada je o Desničinim susretima riječ, pitanje je još važnije jer je Vladan Desnica sam bio odličan prevoditelj $s$ talijanskog i francuskog te ruskog jezika.) Desničini susreti trebali bi njegovati vrlo visoke standarde prijevoda umjetničkih djela (ne samo književnih!) te prijevode društveno-humanističkih i kulturoloških izdanja. Međunarodni sveučilišni centar u Kuli, s mogućnošću involviranja jezgre vrsnih stručnjaka iz Zagreba i Zadra, mogao bi vremenom postati međunarodno žarište specijaliziranih iskusnijih i manje iskusnih prevoditelja, uključujući i najmlađe generacije, koji bi prevodili u timovima istovremeno s raznih jezika na hrvatski i/ili s hrvatskog na razne jezike. Druga programska orijentacija - imanentna Desničinim susretima, prije svega zbog činjenice da je sam Vladan Desnica u oskudnim vremenima pedesetih i šezdesetih godina 20. stoljeća poduzimao sve što je mogao da bi zaštitio Kulu kao kulturno dobro i istovremeno da bi osigurao da ona bude percipirana i kao javno kulturno dobro, otvoreno posjetiteljima - svakako je razvijanje specijalističkih programa kulturnog menadžmenta za mlade stručnjake različitih profesionalnih profila. Ravni kotari su i ekološki i kulturno jedna od najbogatijih i, istovremeno, "najneiskorištenijih" hrvatskih subregija. Uostalom, Kula sama je idealan povod za kreativno propitivanje "kulturnog kapitala" kompleksa samog, Desničina opusa, mnogobrojnih ravnokotarskih baštinskih vrijednosti itd. Povezivanje poslijediplomskih specijalističkih programa s konkretnim subregionalnim projektima imalo bi veliko značenje ne samo za Sjevernu Dalmaciju nego (potencijalno) i za cijelu Hrvatsku pa i druge zemlje. Dakle, ne napuštajući svoju izvornu i provjerenu radnu orijentaciju, Desničini susreti kao jezgra različitih drugih održivih inicijativa, mogu biti istovremeno i "elitne" i "pučke" u umijeću povezivanja "velikih tema" suvremenog doba sa svakodnevnim ljudskim potrebama.

\section{1. 6. Filozofski fakultet: voditelj i administratori}

Voditeljski i administrativni poslovi pretrpjeli su vjerojatno najveće izmjene u odnosu na inicijalno projicirane obveze. Tome je glavni razlog što je nakon odobrenja ovog projekta Sveučilištu u Zagrebu odobren europski projekt Jankovic Castle: historic site, generating sustainable development of the Ravni Kotari region, kojemu smo voditelji dr. sc. Hrvoje Mataković sa Sveučilišta u Zagrebu i ja. Iako su ova dva projekta različito dimenzionirana te se u europskome Međunarodni sveučilišni centar jedva i spominje, postoje i neupitna preklapanja. Budući da se od voditelja s autoritativne strane očekivalo da dâ svoj doprinos realizaciji oba projekta, on je to i prihvatio na temelju uvjeravanja da se ne radi o konfliktu interesa. (Napominjem da u europskom projektu moja profesorska plaća dijelom ulazi u novčanu masu na temelju koje se Sveučilište natjecalo za europska sredstva, što, dakako, ima mnogobrojne implikacije.)

Odobrenje spomenutoga europskog projekta bio je razlog da se odustane od internetske stranice za ovaj projekt jer je zajednički dogovoreno da se sredstvima iz europskoga napravi reprezentativna internetska stranica za sveučilišne inicijative glede MSC-a u Kuli. U iščekivanju interaktivne stranice, najveći dio komunikacije s članovima sveučilišnog projekta realizirao se elektroničkom poštom i povremenim, ali redovitim sastancima s pojedinim ili svim članovima projektnog tima. Osjećam potrebu istaknuti da su unatoč općem pomaku u Vremenskom planu pojedine projektne dionice u osnovi vrlo usuglašeno realizira- 
ne. Kada je i bilo nedoumica što je sve čiji projektni zadatak, uspijevalo se naći primjerena rješenja i, otvoreno rečeno, mislim da je najveći uspjeh ovog projekta što je konstituirana izuzetno profesionalna ekipa stručnjaka za različite poslove u vezi s projektom Međunarodnoga sveučilišnog centra koja je stvorila osjećaj da radi na zajedničkom poslu. Stvorena je i potrebna timska, pozitivno konotirana empatija spram projekta MSC-a u Kuli, što je posebno važno jer se radi o projektu u predjelima gdje su ratni ožiljci još uvijek vidljivi, skoro na svakom koraku.

Voditelji projektnih dionica su od početka rada na projektu podržavali raspravu o tome koji su sve ciljevi ovog projekta. I u tim je raspravama prevladavao vrlo realističan pristup, u biti isti onakav kakav već godinama motivira Desničine susrete, tj. raditi samo ono što je realno izvedivo, a ne gubiti iz vida "strateške ciljeve", što bi u ovom slučaju bili kompleksna revitalizacija Kule i izgradnja MSC-a.

Realističnost se ogleda i u ranoj spoznaji da je za izgradnju funkcionalnijeg MSC-a nužno "izići" iz Kule i pokušati riješiti neka ključna pitanja održivog funkcioniranja MSC-a obnovom i prenamjenom osnovne škole u Islamu Grčkom, razmjerno vrlo velikog i prostranog objekta u središtu sela, nedaleko od Kule. (Voditelj je u skladu sa svojim programskim ovlastima razgovarao s odgovornima na Sveučilištu u Zadru i dobio obećanje da će se rektor prof. dr. sc. Ante Uglešić založiti da se riješe mogući problemi s time u vezi. Smatram da je iznimno važno što i u Zagrebu i u Zadru i dalje postoji najbolja volja da nastavi i, dakako, intenzivira suradnja u realizaciji ovog projekta.)

Kada je riječ o narativnom završnom izvješću, već poodavno je dogovoreno da se njime ne prejudicira ništa što bi prelazilo objektivne granice idejnih nacrta i rješenja. U tom smislu ovaj dokument nudi prije svega pregled najvažnijih obavljenih poslova u svim dionicama projekta, pojašnjava kontekste u kojima su poslovi obavljeni i sugerira, na žalost, nerealiziranu javnu prezentaciju završnih izvješća u radu na pojedinim dionicama. To je s jednim ili dva izuzetka bilo nemoguće napraviti iz jednostavnog razloga što je finalizacija dijela preuzetih obveza trajala praktično sve do nedavno.

Jedina javna evaluacija poslova obavljenih u posljednje dvije godine, kao i u periodu od proteklih četvrt stoljeća, ostvarena je u slučaju Desničinih susreta u Zagrebu i Beogradu u prosincu 2012. godine. S time u vezi objavljena je i jubilarna publikacija, koja je u pdf-u dostupna u kompletnom izvješću.

Sveučilišne ankete o mogućim novim sudionicima projekta MSC-a vođene su isključivo informativno. Bilo ih je više, na različitim fakultetima, ali su svi ograničenog dosega jer je nemoguće dalje ići u poslove koji bi uključivali odlaske u Kulu. Za to sada jednostavno nema preduvjeta, od financijskih i materijalnih nadalje. $U$ razgovorima s rektorom prof. dr. sc. Aleksom Bjelišem te prorektorima prof. dr. sc. Bojanom Baletićem i prof. dr. sc. Melitom Kovačević bilo je riječi o potrebi konstituiranje jednoga autoritativnog sveučilišnog ad hoc ili formalno konstituiranog tijela koje bi preuzelo na sebe "strateško planiranje", ali to, za sada, nije realizirano. Nadamo se da će rezultati ovog projekta u tom smislu biti pozitivan poticaj.

Moje je duboko uvjerenje da je ovaj projekt stvorio realne osnove da se ide dalje, u nove aplikacije i, napose, u međunarodno umrežavanje. U razgovorima sa spomenutim prorektorima bilo je riječi o mogućnostima korištenja postojećih bilateralnih sporazuma Sveučilišta u Zagrebu za projektne zadatke na raznim razinama kojima bi se postupno zgušnjavala mreža involviranih u projektu MSC-a u Kuli. Nakon zaključenja spomenutoga europskog projekta moguće je ići dalje i na mnogo ambicioznije europske fondove u Hrvatskoj nakon 
datuma pristupanja Hrvatske Europskoj uniji (1. srpnja 2013. godine). Osobno mislim da je to najisplativiji pristup.

Naime, mediteranska je perspektiva u ovom slučaju vrlo realna. O tome svjedoči i europski projekt o Kuli. Međutim, ona iziskuje mnogo jače profiliranje inicijativa i interesno umrežavanje nego što je to sada uopće moguće i zamisliti. Realna je i srednjoeuropska perspektiva. O tome se također dosta raspravlja, ali još uvijek nisu doneseni zaključci koji bi bili realna osnova za produbljenije osmišljavanje inicijativa.

Osobno sam mišljenja, kao dugogodišnji voditelj projekta "Triplex Confinium: hrvatska višegraničja u euromediteranskom kontekstu" da je danas najveća hrvatska prednost transregionalna situiranost (Sredozemlje - Srednja Europa - Jugoistočna Europa). Povijesno to nije obično bilo tako, ali bi u budućnosti moglo biti, a to znači da su mjesta poput Kule Stojana Jankovića u Islamu Grčkom već i simbolički predodređena biti mjesta kreativnih dijaloga i međunarodne sveučilišne suradnje. U tom je smislu ovaj projekt uspjeh već time što je započet, a još veći uspjeh time što su sve predviđene dionice realizirane na zavidnoj profesionalnoj razini.

\section{1. 7. Ključni vanjski suradnik}

Ključni vanjski suradnik, dr. sc. Uroš Desnica, znanstveni savjetnik u trajnom zvanju, u Projektu MSC-a predstavlja vlasnike Kule, potomke pisca Vladana Desnice te udrugu "Društvo za obnovu i revitalizaciju Kule Stojana Jankovića - Mostovi". U svim fazama realizacije Projekta vrlo je aktivno sudjelovao u radu na projektnim dionicama A, B, C, D, E i F u skladu s odrednicama u Vremenskom planu aktivnosti: "Pribavljanja, priprema, obrade i tumačenja svih vrsta dokumentacije, arhivskih i novijih nacrta zgrada i terena, mapa, arhivskih i fotografskih materijala, pisanje specifičnih tematskih materijala potrebnih u raznim dionicama i u završnom izvješću”. Projektne djelatnosti dr. sc. Desnice moguće je razvrstati u dvije skupine: prvo, izrada autorskih tekstova i priloga za potrebe rada na projektnim zadatcima, i drugo, pružanje praktične podrške projektnim partnerima, prema potrebi i dogovoru, u Zagrebu ili u kompleksu Kule Jankovića u Islamu Grčkom. Potonje se odnosi i na druge članove spomenute udruge. Dragocjeni su autorski radovi dr. sc. Desnice jer su s jedne strane svjedočanstvo najboljeg poznavatelja baštine Kule te, s druge strane, najupućenijeg vlasnika u stanje svih poslova s Kulom u vezi, neovisno tko se sve javljao kao akter. (Svi su ovi radovi dostupni u završnom izvješću ključnoga vanjskog suradnika. Također, trudom dr. sc. Desnice napravljeni su opširni kritički komentari i konkretne sugestije za proširenja/poboljšanja triju važnih tekstova izrađenih u okviru ovog projekta: Komentar prijedloga idejnog nacrta MSC-a profesora Brauna, komentar prijedloga muzeološke koncepcije u Kuli dr. sc. Babića i komentar studije Ivana Basića o samoodrživosti i baštinskim vrijednostima Kule (inače, napravljen za izvanprojektne potrebe). Druga važna aktivnost dr. sc. Desnice i drugih članova udruge "Društvo za obnovu i revitalizaciju kule Stojana Jankovića - Mostovi” bila je pružanje podrške svim partnerima na projektu, kako u Zagrebu tako i u Islamu Grčkom, odnosno u kompleksu i parku Kule.

Ta raznorodna i svestrana podrška uključivala je:

- pribavljanje, obradu i pripremu dokumentacije (arhivski materijali, nacrti, planovi, fotodokumentacija, specifične informacije - korištenjem bogatih arhiva Kule Stojana Jankovića, arhive Vladana Desnice, arhiva sadašnje generacije vlasnika Kule);

- sudjelovanje i konkretna suradnja u praktički svim terenskim istraživanjima i predloženim projektnim rješenjima. Konkretnije: 
1. Za potrebe Arhitektonskog fakulteta pribavljena je i učinjena dostupnom vrlo opsežna dosadašnja arhitektonska dokumentacija za Kulu Jankovića kao cjelinu te za "sjevernu frontu" napose. Pod imenom Povijesni nacrti za nove namjene Sjeverne fronte (tj. niza zgrada koje čine MSC u ovom projektu) uključena su i dva ranija idejna rješenja za njezinu obnovu (smještajni kapaciteti, blagovaonica i knjižnica) te znatno razrađeniji idejni nacrt tvrtke D\&Z iz 2009. godine za MSC, koji je bio na pragu konzervatorskog odobrenja, ali se pokazao neadekvatnim za budućeg korisnika. Također je provedena detaljna diskusija o Idejnom rješenju MSC-a izrađenom u ovom Projektu te su autorima dostavljeni pisani, konstruktivni prijedlozi i komentari prvog, a onda i drugog predloženog rješenja.

2. Za potrebe Agronomskog fakulteta pribavljeni su postojeći planovi i nacrti za parkovni dio Kule Jankovića te popisi vrsta drveća u arboretumu, zatim njihovi prostorni rasporedi itd. Popisani su izvori vode (jedan stalni i više sezonskih). Isti su identificirani na terenu, u raznim dijelovima parka. Pribavljena je, iz porodičnih arhiva, i fotodokumentacija o stanju arboretuma u raznim vremenskim periodima prije rata, koja je posebno potrebna sada kada su dijelovi postali teško prepoznatljivi. Identificirani su na terenu i glavni putovi i nekoliko puteljaka unutar parka, lokacije suhozida, lokacije drvoreda (koji se sada tek djelomično naziru), zone pojedinih vrsta bilja itd. Također su na terenu raspravljeni razni detalji idejnog hortikulturnog rješenja.

3. Za potrebe Geodetskog fakulteta pribavljena je dokumentacija iz katastra i gruntovnice o relevantnim parcelama za MSC te parkovni dio i ostatak imanja, potom, detaljni precizni nacrti postojećeg stanja. Pružena je pomoć u raščišćavanju raslinja kako bi se mogla obaviti što kvalitetnija snimanja zgrada predviđenih za MSC te drugih objekata kompleksa.

4. Za Filozofski fakultet (u sklopu zadatka izrade muzeološke studije za povijesne dijelove Kule) pribavljena je, odnosno izrađena, potrebna dokumentacija: tlocrti i nacrti te položaj unutar kompleksa svih prostora (uključivo precizne površine) predviđenih za potrebe budućeg muzeja: za unutrašnje prostore - za muzejske postave, depoe te pomoćne prostorije budućeg muzeja, kao i za vanjske površine te potencijalne sadržaje/atrakcije. Također je pribavljena i organizirana u cjeline dokumentacija o svim sačuvanim zbirkama te, koliko je bilo moguće, fotodokumentacija artefakata pojedinih zbirki. Detaljno, i u pisanom obliku i u usmenoj diskusiji, dani su komentari i sugerirane eventualne dopune/izmjene predložene muzeološke koncepcije muzeja u Kuli.

5. Nadalje, također za potrebe Filozofskog fakulteta, vezano uz aktivnosti oko Desničinih susreta, pribavljeni su relevantni dijelovi dokumentacije o Vladanu Desnici (prikupljanje i izbor dijelova arhivske građe raznih vrsta, kao i dokumentacije i fotodokumentacije o Vladanu Desnici i Kuli Jankovića iz arhiva Vladana Desnice, arhiva Kule Jankovića te iz porodičnih arhiva Vladanovih potomaka i Vladanovih rođaka, posebno gosp. Stojana Desnice.

U zaključku, ostvareni su svi poslovi kako su planirani u Projektu te u opsegu koji se pokazao potrebnim. To je ponekad bilo i u znatno širem opsegu od prvotno planiranih (i za to predviđenih sredstava), ali je to, s druge strane, omogućilo da se Projekt uspješno i optimalno realizira. 


\section{Uklopljenost projekta u ciljeve programa}

Projekt je nesumnjivo doprinio realizaciji programskog cilja "Zajedno" jer su projektni ciljevi shvaćeni kao zajednička obveza, a pojedinačna postignuća kao međusobni radni poticaji. Naglasio bih i vrlo koristan učinak međusobnog učenja, imajući na umu da projektni tim čine ljudi vrlo različitih profesionalnih usmjerenja. Kada je riječ o cilju "Svijet”, uspjeh je postignut u mjeri u kojoj nitko nije radio svoje poslove polazeći od toga da u slučaju jednoga ratom teško pogođenog područja i objekta treba primjenjivati bilo kakve druge kriterije nego optimalne, svjetske, tim više što je riječ o projektu Međunarodnoga sveučilišnog centra, koji bi morao biti reprezentativan za Sveučilište u Zagrebu i Hrvatsku kao državu baš zato što je riječ o objektu i području koje se oslobađa od tereta bliske prošlosti. Bilo da je riječ o načinu kako se rješavalo projektne zadatke u bilo kojoj dionici, bilo da je riječ o tome kako bi MSC trebao funkcionirati, svjetsko obzorje je bilo opredjeljujuće. U slučaju cilja "Prostor" postignuti su također zamjetni rezultati, prije svega zbog toga što je riječ o koncepciji MSC-a u predjelu gdje se Sveučilište u Zagrebu inače često ne javlja, a koje je svojom kompleksnošću i objektivno realnim potencijalima vrijedno ulaganja o kojima je ovdje riječ. Drugo, kada je riječ o mikrolokalitetu i Kuli kao “mjestu”, rješavanje različitih projektnih zadataka još je jednom pokazalo da je Hrvatska zemlja velikih regionalnih (prostornih) razlika i da budućnost Sveučilišsta u Zagrebu ovisi i o tome kako će te raznolikosti umjeti integrirati u svojim razvojnim projektima.

\section{$\cos$}

\section{Literatura}

Aničıć, Branka. 2013. Studija vanjskog prostora Kule i Međunarodnog sveučilišnog centra, sa smjernicama za uređenje (v. http://kula-jankovica.unizg.hr/hr/medunarodni-sveucilisni-centar/ agronomski-fakultet/)

Basić, Ivan. 2010. Od domus episcopi do Kule Jankovića. Prostorni razvoj Kule Stojana Jankovića u Islamu Grčkom. Zagreb: Biblioteka Desničini susreti - Filozofski fakultet Sveučilišta u Zagrebu - Centar za komparativnohistorijske i interkulturne studije - FF-press.

Braun, Alan. 2013. Idejno rješenje rekontrukcije i prenamjene dijela sklopa Kule Stojana Jankovića, Islam Grčki, u Mešunarodni sveučilišni centar (v. http://kula-jankovica.unizg.hr/hr/medunarodni-sveucilisni-centar/arhitektonski-fakultet/).

Č́nnnelić, Milana i Marijeta Rajković Iveta, 2010. Zapisi iz gornjih Ravnih Kotara: Etnološki, povijesni i muzeološki prilozi o Islamu Latinskom, Islamu Grčkom, Kašiću i Podgradini. Zagreb: Centar za komparativnohistorijske i interkulturne studije Filozofskog fakulteta - FF-press.

RoksAndić, Drago. Završni izvještaj o izvršenju projekta (sadržajni dio). Projekt Međunarodni sveučilišni centar u Islamu Grčkom i Mediteranska akademska zajednica: Razvoj i perspektive. Zagreb, lipanj 2013.

Roksandić, Drago, Ivana Cvijović Javorina, ur. 2013. Intelektualci i rat, 1939.-1947. Zbornik radova s međunarodnog skupa “Desničini susreti 2012.", Svezak 1. i 2. Zagreb: Biblioteka Desničini susreti - Filozofski fakultet Sveučilišta u Zagrebu - Centar za komparativnohistorijske i interkulturne studije - FF-press.

Roksandić, Drago, Ivana Cvijović Javorina, ur. 2013. Vladan Desnica $i$ Desničini susreti: pogled unatrag i pogled unaprijed, Dijalog spovodom, 5, Zagreb: Biblioteka Desničini susreti - Filozofski fakultet Sveučilišta u Zagrebu - Centar za komparativnohistorijske i interkulturne studije - FF-press. 